\title{
A CAPACIDADE DE AGIR DA PESSOA COM DEFICIÊNCIA: PROPOSTA HERMENÊUTICA DA NORMA POSTA RELATIVA AO MAIOR ACOMPANHADO
}

\author{
THE ABILITY TO ACT OF THE PERSON WITH DISABILITIES: HERMENEUTIC PROPOSAL \\ OF THE NEW PORTUGUESE RULE
}

\section{Hugo Cunha Lança}

CEDIS - Faculdade de Direito da Universidade Nova de Lisboa Instituto Politécnico de Beja - Portugal. Doutor em Direito, desde 2015, pela Faculdade de Direito da Universidade do Porto. Investigador Doutorado Integrado no CEDIS - Faculdade de Direito da Universidade Nova de Lisboa. Professor Adjunto - Instituto Politécnico de Beja. E-mail: hdlanca@gmail.com

Convidado

RESUMO:Neste artigo pretende-se interpretar o novo regime jurídico do maior acompanhado, em diálogo com o regime deposto, avaliando criticamente as soluções apresentadas, trazendo luz para uma temática quase sempre tecida com os tons obscuros do barroco. Dessarte, importa indagar sobre quem reúne os requisitos subjetivos para beneficiar de medidas de acompanhamento e aquilatar quais as limitações legítimas à capacidade de agir do maior acompanhado. Porque a legislação é recente e introduz uma mudança de paradigma, as dúvidas subjugam as dúvidas, pelo que urge suscitar, para meditar, sobre um conjunto de questões, mormente a autorização para internamento, a alienação de património, a escolha do acompanhante, o exercício dos direitos pessoais do beneficiário, inter alia.

Palavras-chave: Pessoa com deficiência. Dignidade. Capacidade jurídica.

SUMMARY:In this article we intend to interpret the new legal regime of the person with disabilities, in dialogue with the deposed regime, critically evaluating the solutions presented, bringing light to a theme almost always woven with the obscure tones of the baroque. Because the legislation is recent and introduces a paradigm shift, doubts overwhelm doubts, so it is imperative to meditate on a set of issues, especially the authorization for hospitalization, the alienation of assets, the choice of the companion, the exercise of the beneficiary's personal rights, inter alia.

Keywords: Disabled person. Dignity. legal capacity.

SUMÁRIO: Introdução; 1. A norma social e a pessoa com incapacidades: os deficientes; 2. Análise crítica ao regime jurídico revisto; 3. Os princípios que norteiam (deviam nortear) o regime jurídico do maior acompanhado; 4. Análise crítica à norma posta; Conclusão; Bibliografia. 


\section{INTRODUÇÃO}

Quando cotejamos a versão originária do Código Civil português, constatamos a existência de dois Institutos passíveis de se aplicarem às pessoas que não têm o discernimento necessário para avaliar as consequências dos seus atos jurídicos. Mais do que isso, quando confrontamos a law in the books com a law in action, verificamos que a existência de uma deficiência tinha como consequência quase direta e necessária o deferimento de uma incapacidade jurídica de exercício, por regra a interdição ${ }^{1}$. O que, infelizmente, não deve pasmar o intérprete: o código é um produto genético da década de 60 e traduz um país ainda oprimido pela ditadura, encerrado por fronteiras físicas e culturais ${ }^{2}$. Dessarte, aquele era um tempo em que as mulheres eram privadas dos mais básicos direitos, em que a unidade familiar se construía pelo esmagamento dos sonhos escritos no feminino, um tempo em que o Direito ignorava a dimensão pessoal das normas, construindo numa lógica patrimonialística, sendo, portanto, evidentemente um ordenamento jurídico refém dos arquétipos do seu tempo ${ }^{3}$.

Cinquenta anos sobre a norma, quarenta anos depois do dia inicial inteiro e limpo, onde emergimos da noite e do silêncio e livres habitamos a substância do tempo, tendo por premissa os avanços da medicina e uma nova mentalidade que começa a habitar na sociedade, não podemos continuar a colocar vinho novo em odres velhos, exigindo-se uma reinterpretação dos Institutos que regulam a capacidade de agir das pessoas com deficiência.

Neste texto,pretende-se interpretar o novo regime jurídico do maior acompanhado, avaliando criticamente as soluções apresentadas, trazendo luz para uma temática quase sempre tecida com os tons obscuros do barroco.

\section{A NORMA SOCIAL E A PESSOA COM INCAPACIDADES: OS DEFICIENTES}

Tem razão o Senhor Presidente da República Portuguesa quando afirmou que o otimismo crónico é ligeiramente irritante, pelo que se o intérprete deve ter como horizonte interpretativo o Dever Ser, nunca pode ignorar que se movimenta no espaço do Ser. E, infelizmente, o Mundo do Ser ainda é habitado por um conjunto de preconceitos e de discriminações que condenam ao ostracismo as pessoas com deficiências, porquanto muitos ainda se esforçam por ignorar que a deficiência não define uma pessoa e que, quer personagens míticas do nosso espaço cultural quer milhares e milhares de cidadãos anónimos, em heterogéneas áreas, tiveram a sapiência, a sagacidade e, tantas vezes, a resiliência, para quotidianamente nos recordar que, na esmagadora maioria dos casos, as limitações não são pessoais, mas resultam de uma arquitetura social que, presa a estranhos paradigmas de normalidade, é inapta para lidar com a diferença.

Sendo insofismável a premissa, não concebo o Direito como uma realidade amorfa que se conforma com os vícios da sociedade, antes entendo-o como uma realidade axiológica com vocação para delinear caminhos, a constante e perpétua vontade de dar a cada um o que é seu, numa incessante procura do Bom, do Belo e do Justo.

Consequentemente, vencidos os preconceitos herdados do modelo caritativo primeiro, e do modelo médico, posteriormente, que interpretava a pessoa com deficiência como um doente (que, como Foucault ensina, esteve secularmente condenado a estar encerrado longe dos olhares

\footnotetext{
${ }^{1}$ Tendo por paradigma o ano de 2016, foram decretadas 3136 interdições e apenas 259 inabilitações, conforme os dados recolhidos das estatísticas da justiça.

${ }^{2}$ Sendo que, o regime de incapacidades para cidadãos adultos foi inspirado no código civil italiano de... 1942.

3 Em sentido análogo, PEREIRA, André Gonçalo Dias - A Capacidade para Consentir: um Novo Ramo da Capacidade Jurídica. In: Comemorações dos 35 anos do Código Civil e dos 25 anos da Reforma de 1977 / Faculdade de Direito da Universidade de Coimbra. Coimbra: Coimbra Editora, 2004-2006, p. 200.
}

Revista de Direito Brasileira | Florianópolis, SC | v. 23 | n. 9 | p. 323-341 | Mai./Ago. 2019 
da sociedade), e em que paulatinamente começa a ser trilhado um modelo baseado em Direitos, que prescreve a concretização dos direitos humanos básicos de qualquer pessoa, tais como o direito à vida, à saúde, à educação, ao trabalho ou à cultura, o ordenamento jurídico não pode ficar imune aos lampejos de modernidade que começam a ser sussurrados pelas organizações que protegem as pessoas com deficiência.

Ciente de que a sociedade não muda por Decreto-Lei, os valores da dignidade humana reclamam que as pessoas com deficiência não continuem a ser espoliadas dos seus direitos fundamentais, mormente dos seus direitos pessoais, exigindo-se uma nova mentalidade sobre a sua capacidade jurídica de agir, tendo a Pessoa concreta e a sua idiossincrasia por premissa, solução incompatível com a consagração abstrata de categorias tipos, transformando um indivíduo numa parte indistinguível de um grupo. Dessarte,a incapacidade deve ser fixada casuisticamente em função da concreta idiossincrasia daquela Pessoa concreta, em determinado momento específico, tendo por paradigma o princípio da intervenção mínima. Até porque a questão da capacidade é, hoje, nuclear:

"se nos sistemas esclavagistas a luta pela dignidade humana foi diretamente uma luta pela personalidade, nos sistemas modernos [...] a luta pela personalidade é diretamente uma luta pela capacidade. Luta que está longe do seu fim, se nos lembrarmos das várias capitis deminutiones que ainda se admitem nos "bons costumes" contemporâneos: incapacidades derivadas da etnia, da idade, da nacionalidade, etc." $"$.

\section{ANÁLISE CRÍTICA AO REGIME JURÍDICO REVISTO}

Porque o Direito é filho do devir da sociedade e não é imune aos seus caprichos e preconceitos, coevo ao pensamento da época, o Código Civil português, na sua versão original, no que concerne à capacidade jurídica, partindoda premissa de que as pessoas podem ser sujeitos de quaisquer relações jurídicas (nisto consistindo a sua capacidade jurídica, cf.art. 67. ${ }^{\circ}$, do Código Civil), escorraçava do exercício dos seus direitos as pessoas com deficiências. Com efeito, no que concerne à capacidade de agir, constatava-se a existência de um sistema dualista com o desiderato de, alegadamente,proteger, quer perante terceiros que procurassem aproveitarse da inaptidão quer numa lógica de autoproteção, todos aqueles que carecem de capacidade plena para participar de per si no comércio jurídico, através dos Institutos da interdição e da inabilitação. A magna quaestioera, e é, que "entre a protecção de um homem e a sua liberdade existe um conflito ou antagonismo inevitável"5, sendo crucial afiançar que a proteção do indivíduo não "pode ir ao ponto de amputar totalmente a sua capacidade civil""

No que diz respeito à interdição, podiam ser interditos do exercício dos seus direitos todos aqueles que por anomalia psíquica, surdez-mudez ou cegueira se mostrem incapazes de governar suas pessoas e bens (sendo que a melhor hermenêutica da norma considera este elenco exemplificativo, logo suscetível de ser aplicado a outras situações que inquinem a capacidade de o agente expressar conscientemente a sua vontade).

Dessarte, a interdição foi altruisticamenteconcebida, conforme resulta do anteprojeto do Código Civil, como

\footnotetext{
${ }^{4}$ ORLANDO, Carvalho - Teoria Geral do Direito Civil. $3^{\text {a }}$ Ed. Coimbra: Coimbra Editora, 2012, p. 193.

${ }^{5}$ ALVES, Raúl Guichard - Alguns Aspectos do Instituto da Interdição. In: Interdição e Inabilitação. [Em linha]. Lisboa: $\quad$ CEJ. [Consult. 01 dez. 2017]; Disponível em: www.cej.mj.pt/cej/recursos/ebooks/civil/Interdicao_inabilitacao.pdf, p. 41.

${ }^{6}$ COSTA, Marta - A Desejável Flexibilidade da Incapacidade das Pessoas Maiores de Idade. "Lusíada". Lisboa, n. ${ }^{\circ}$ 7, p. 125.
} 
"medida judiciária aplicável aos portadores de deficiência físiopsíquicas tão graves que eliminem a vontade ou o entendimento e em que, por isso mesmo, a incapacidade só pode ser suprida por meio de representação, cabendo a um tutor agir em nome do incapaz"7.

Concludentemente, a consequência jurídica da interdição, numa lógica inspirada no modelo da incapacidade por menoridade,traduzia-se em equiparar o interdito ao menor, sendo-lhe aplicáveis, com as necessárias adaptações, as disposições que regulam a incapacidade por menoridade $e^{8}$ fixam os meios de suprir o poder paternal(art. 139. ${ }^{\circ}$, do Código Civil), $i$ e., era-lhe nomeado um representante legal que o substituía no comércio jurídico, tornando irrelevante a vontade do interdito, que, numa primeira leitura, era impedido de exercer direitos que eram seus e apenas seus. Posto isto, não pode causar estranheza ao intérprete que a norma civil mantenha os preconceitos de 1966 e que, reiteradamente, viole direitos fundamentais do cidadão com deficiência, estuprando a exigência de constitucionalização do direito civil, inscrita no n. ${ }^{\circ} 3$, do art. 293. ${ }^{\circ}$, da Constituição da República Portuguesa (versão originária).

Enfatize-se que, era doutrina firme, a incapacidade do interdito não se limitava aos atos de natureza patrimonial, à "cura" dos seus bens, mas também abrangia as dimensões pessoas do sujeito ${ }^{9}$, mormente toda uma panóplia de constrangimentos e limitações legais, apenas concebíveis quando apelamos aos mais vis preconceitos: assim, o texto da norma civil [em inequívoca violação da norma constitucional], determinava que TODOS os interditos por anomalia psíquica eram inaptos para casar (al. b), do art. 1601. ${ }^{\circ}$ ), para perfilhar (n. ${ }^{\circ}$ 1, do art. $1850 .^{\circ}$ ), eram liminarmente afastados do exercício da autoridade parental (al. b), do art. 1973. ${ }^{\circ}$ ), não podiam ser tutores (al. b.), do art. $1933 .^{\circ}$ ), nem realizar testamento (al. b), do art. $2189 .^{\circ}$ ).

Acrescia que, porque este era um processo judicial, decorriam múltiplos constrangimentos da sua judicialização, nomeadamente a publicidade inerente aos trâmites judiciais. Como, "o excesso de "civilismo" do legislador, mais preocupado com o Direito comparado do que com o País real, manteve a interdição como um instituto de "ricos"" 10 .

No que concerne ao Instituto da inabilitação, podiam

ser inabilitados os indivíduos cuja anomalia psíquica, surdez-mudez ou cegueira, embora de carácter permanente, não seja de tal modo grave que justifique a sua interdição, assim como aqueles que, pela sua habitual prodigalidade $^{11}$ ou pelo abuso de bebidas alcoólicas ou de estupefacientes ${ }^{12}$, se

\footnotetext{
${ }^{7}$ Américo Campos COSTA, apud. TRABUCO, Cláudia - O Regime das Incapacidades e Respectivo Suprimento: perspectivas de reforma. [Em linha]. Lisboa: FDUNL. [Consult. 01 set. 2017]; Disponível em: www.fd.unl.pt/docentes_docs/ma/ct_MA 5013.doc, p. 6.

${ }^{8} \mathrm{O}$ que suscita complexas questões, mormente, se as menoridades especiais também se aplicam aos interditos.

${ }^{9}$ Assim, ALVES, Raúl Guichard - Alguns Aspectos do Instituto da Interdição. In: Interdição e Inabilitação. [Em linha]. Lisboa: CEJ. [Consult. 01 dez. 2017]; Disponível em:
} www.cej.mj.pt/cej/recursos/ebooks/civil/Interdicao_inabilitacao.pdf, p. 46.

${ }^{10}$ CORDEIRO, António Menezes - Da situação jurídica do maior acompanhado. Estudo de política legislativa relativo a um novo regime das denominadas incapacidades dos maiores. [Em Linha]. Lisboa. [Consult. Abril de 2018]. Disponível em: http://www.smmp.pt/wp-content/uploads/Estudo_Menezes-CordeiroPinto-MonteiroMTS.pdf, p. 16.

${ }^{11}$ A lei não a define, mas "podemos avançar que a prodigalidade resulta não - ou não apenas - de despesas elevadas em relação aos rendimentos, mas de despesas injustificadas e reprováveis, que ponham em causa o capital ou os seus bens de que provêm os rendimentos" (CORDEIRO, António Menezes - Da situação jurídica do maior acompanhado. Estudo de política legislativa relativo a um novo regime das denominadas incapacidades dos maiores. [Em Linha]. Lisboa. [Consult. Abril de 2018]. Disponível em: http://www.smmp.pt/wp-content/uploads/Estudo_MenezesCordeiroPinto-MonteiroMTS.pdf, p. 31).

${ }_{12}$ Importa sublinhar que "o alcoolismo crónico e a toxicomania incurável podem ser convolados para anomalias psíquicas" (CORDEIRO, António Menezes - Da situação jurídica do maior acompanhado. Estudo de política legislativa relativo a um novo regime das denominadas incapacidades dos maiores. [Em Linha]. Lisboa. [Consult.

Revista de Direito Brasileira | Florianópolis, SC | v. 23 | n. 9 | p. 323-341 | Mai./Ago. 2019 
mostrem incapazes de reger convenientemente o seu património(art. $152 .^{\circ}$, do Código Civil),

sendo que, os inabilitados eram assistidos por um curador, a cuja autorização estão sujeitos os actos de disposição de bens entre vivos e todos os que, em atenção às circunstâncias de cada caso, forem especificados na sentença (art. 152. ${ }^{\circ}$, do Código Civil), aplicando-se, mutatis mutandis, o regime das interdições (art. 156. ${ }^{\circ}$, do Código Civil, todos agora revogados). Dessarte, contrariamente à rigidez do regime da interdição, a inabilitação não correspondia a uma incapacidade geral de exercício, antes circunscrita a determinados atos ou categorias de atos, passível de ser concretizada por sentença judicial, tendo em conta as especificidades do inabilitando.Por isso mesmo, na esteia de Mota PINTO $^{13}$, sempre entendi que os atos não patrimoniais não se subjugavam à limitação de capacidade de agir.

Exposto sumariamente o regime anterior, é fácil inferir que sobejavam motivações para censura. Ab initio, sendo comum vermos escrito que a ratio legis dos Institutos da interdição e da inabilitação era proteger os interesses das pessoas que têm uma capacidade diminuída, importa averiguar criticamente se estes institutos cumpriam a missão para a qual foram desenhados.

Para responder ao quesito, é imprescindível dissecar as normas postas, sem esquecer uma hermenêutica sistemática, porquanto cada norma não é uma ilha e o Direito ainda é um Sistema.

Um primeiro problema hermenêutico era a imperatividade de densificar o conceito de anomalia psíquica, porquanto o legislador, sabiamente, não nos oferecia uma definição, optando pelo recurso a um conceito indeterminado ${ }^{14}$

"de maneira intencional para compreender qualquer perturbação das faculdades intelectuais ou intelectivas - afectando a inteligência, a percepção ou a memória - ou faculdades volitivas - atinentes quer à formação da vontade quer à sua manifestação. Teve-se aqui em conta, nomeadamente, que há enfermidades e deficiências mentais nas quais o primeiro aspecto permanece suficientemente intacto, mas a componente volitiva surge morbosamente alterada" ${ }^{15}$.

Uma outra querela interpretativa, que fazia divergir a doutrina de mais alto coturno, prende-se com a natureza taxativa ${ }^{16}$ ou exemplificativa ${ }^{17}$ das causas de interdição e de inabilitação. Como supra deixei escrito, sempre me pareceu que a norma devia interpretar-se exemplificativa, de molde a impedir que situações análogas tivessem um tratamento jurídico disforme.

Abril de 2018]. Disponível em: http://www.smmp.pt/wp-content/uploads/Estudo_Menezes-CordeiroPintoMonteiroMTS.pdf, p. 19).

${ }^{13}$ PINTO, Carlos Mota - Teoria Geral de Direito Civil. 4. ${ }^{a}$ Ed. Coimbra: Coimbra Editora, 2005, p. 242.

${ }^{14}$ Solução que se aplaude, reconduzindo a sua densificação para a ciência medica-psiquiátrica, possibilitando uma osmose entre os avanços técnicos e a atualidade da norma.

${ }^{15}$ ALVES, Raúl Guichard - Alguns Aspectos do Instituto da Interdição. In: Interdição e Inabilitação. [Em linha]. Lisboa: CEJ. [Consult. 01 dez. 2017]; Disponível em: www.cej.mj.pt/cej/recursos/ebooks/civil/Interdicao_inabilitacao.pdf, p. 51.

${ }^{16}$ Assim, ALVES, Raúl Guichard - Alguns Aspectos do Instituto da Interdição. In: Interdição e Inabilitação. [Em linha]. Lisboa: CEJ. [Consult. 01 dez. 2017]; Disponível em: www.cej.mj.pt/cej/recursos/ebooks/civil/Interdicao_inabilitacao.pdf, p. 47.

${ }^{17}$ Assim, TRABUCO, Cláudia - O Regime das Incapacidades e Respectivo Suprimento: perspectivas de reforma. [Em linha]. Lisboa: FDUNL. [Consult. 01 set. 2017]; Disponível em: www.fd.unl.pt/docentes docs/ma/ct MA 5013.doc, p. 6., CORDEIRO, António Menezes - Da situação jurídica do maior acompanhado. Estudo de política legislativa relativo a um novo regime das denominadas incapacidades dos maiores. [Em Linha]. Lisboa. [Consult. Abril de 2018]. Disponível em: http://www.smmp.pt/wpcontent/uploads/Estudo_Menezes-CordeiroPinto-MonteiroMTS.pdf, p. 18.

Revista de Direito Brasileira | Florianópolis, SC | v. 23 | n. 9 | p. 323-341 | Mai./Ago. 2019 
Outra celeuma, relaciona-se com a necessidade de densificar o conceito de incapaz de se governar a si e ao seu património, cuja concretização era decisiva para operacionalizar os Institutos.

Sem eufemismos, para benefício da exposição, existia uma imensa margem de discricionariedade do julgador, que, amiúde, se confundia com arbitrariedade. Até porque, o julgador, por formação, não tem vocação para aferir se a patologia do incapaz o impedia de navegar no tráfego jurídico e falta na nossa cultura e prática judicial a participação de equipas multidisciplinares que reúnam, inter alia, médicos, psicólogos eassistentes sociais, de modo a que a decisão seja o mais objetiva possível [tendo por parâmetro a subjetividade do sujeito].

Acrescia que [como se os problemas hermenêuticos fossem insuficientes] o legislador misturava o que,quiçá, não deveria ser confundido, e a norma aglutinava as situações de anomalia psíquica com duas deficiências físicas: cegueira e surdez-mudez! Se tratar de forma igual aquilo que é diferente suscita críticas, a ambiguidade é acrescida quando procurávamos compreender porque o legislador se refere a estas, e apenas a estas, deficiências funcionais. Dessarte,

"só razões "historicamente contingentes" e já superadas, podem explicar a opção da lei. A qual, de resto, provém do Código de 67 e já então era deplorada, afirmando, por exemplo, José TAVARES que o sistema legal [...] é muito incompleto, porque [...] não tem protecção jurídica para as outras incapacidades orgânicas"18.

O tema era especialmente delicado porque não se podia aceitar acriticamente que uma pessoa com deficiência física fosse liminarmente estropiadado tráfego jurídico, quando mantinha intacta a sua dimensão volitiva, imaculada a sua capacidade intelectual, pelo que, e as mais das vezes apenas por constrangimentos ambientais, poderia carecer de alguém que a auxiliasse a expressar a sua vontade, sendo, portanto, inadmissível castigá-lo com a sujeição ao regime jurídico da representação. Com efeito,

constitui, na verdade, uma evidência que estas limitações de carácter físico não implicam necessariamente que uma pessoa não se encontre em condições de conduzir a sua própria vida, atenta inclusivamente a profunda alteração tecnológica, que tem permitido aumentar substancialmente a autonomia $e$ qualidade de vida de quem apresenta tais limitações ${ }^{19}$.

A questão é crucial, porquanto a representação silencia a voz do interdito, impedindo-o de expressar livremente a sua vontade, deixando-o prisioneiro das escolhas de outros. Com efeito, é preciso não ignorar que a nomeação de um tutor ou curador traduz sempre uma restrição à capacidade de autodeterminação de uma pessoa. Por outro lado, esta marginalização que afasta o cidadão da participação na Ágora tem consequências terapêuticas terríveis, conspurcando a autoimagem e autoestima do visado.

Finalmente, era profusamente criticado o facto de o regime deposto estatuir situações rígidas e uniformes para toda uma panóplia de situações divergentes, alegando-se que era crucial que o regime fosse flexível, de modo a permitir interpretar a idiossincrasia de cada uma das pessoas a quem se aplica, aquilatar da capacidade [e incapacidade] daquela pessoa em concreto, indagar se aquela pessoa tem capacidades intelectuais, volitivas e emocionais que lhe permitam decidir naquele caso específico. Porque, in casu, generalizar é criminoso, por ignorar que cada pessoa tem a sua ipseidade e que esta não pode ser afastada pelo conforto de uma solução

${ }^{18}$ ALVES, Raúl Guichard - Alguns Aspectos do Instituto da Interdição. In: Interdição e Inabilitação. [Em linha]. Lisboa: CEJ. [Consult. 01 dez. 2017]; Disponível em: www.cej.mj.pt/cej/recursos/ebooks/civil/Interdicao_inabilitacao.pdf, p. 62.

${ }^{19}$ Resolução do Conselho de Ministros n. ${ }^{\circ}$ 63/2015, que aprova a estratégia para a proteção do idoso. Revista de Direito Brasileira | Florianópolis, SC | v. 23 | n. 9 | p. 323-341 | Mai./Ago. 2019 
genérica. Ademais, solução oposta contrariaria o texto constitucional sendo axiológico que as normas civis devem ser interpretadas em conformidade com a constituição e com o direito internacional convencional.

Por estas e por múltiplas outras razões que brevitatis causaaqui não menciono, a lei agora revogada era vítima de uma panóplia de assertivas críticas: (i) por criar uma situação permanente $^{20}$ de inferioridade jurídica [ainda que, nas mais das vezes, por piedosas razões], (ii) por ser estigmatizante, quer pelo conteúdo dos institutos quer pela sua nomenclatura ${ }^{21}$ (iii) por amiúde privilegiar mais os interesses dos familiares do que os legítimos direitos da pessoa que visa promover, (iv), por ter perversas consequências terapêuticas, mormente por contribuir para a infantilização/menorização da pessoa com deficiência ${ }^{22}$, pelo que amiúde encontra grande resistência do interditando, (v) por ser demasiado rígida, não atendendo à variação das capacidades intelectuais, emotivas e volitivas dos sujeitos, (vi), um processo demasiado longo ${ }^{23}$ e oneroso, e, (vii), pelo seu cariz patrimonialístico, (viii)tendo por primeira finalidade satisfazer, de modo burocrático, a segurança no tráfego jurídico ${ }^{24}$. Em suma, alegava-se que

“o direito português se tem mostrado pouco receptivo à valorização da autonomia do sujeito com capacidades diminuídas, bem como à sua inserção no tráfego jurídico como forma de atenuação, ou mesmo de eliminação da estigmatização, apesar de os progressos da ciência psiquiátrica irem no sentido oposto, promovendo o respeito pela vontade e liberdades humanas, de forma a invadir o menos possível a esfera de actuação de cada um"25.

Dessarte, o fascínio pela segurança jurídica, tal com o deslumbramento de Ícaro pela beleza do Sol, fez o legislador ignorar que a sua primordial preocupação é a proteção da Pessoa sendo que a circunstância de alguém

"padecer de uma debilidade que limita as suas capacidades físicas e mentais não significa nem deve determinar que esta fique, por esse motivo, legalmente impossibilitada de exercer todos os direitos de que é titular, antes devendo a extensão da diminuição da capacidade ser fixada casuisticamente, em função das circunstâncias concretas" 26 .

Dito [tudo] isto, quiçá por algum conservadorismo dogmático, quiçá pelas minhas características aristotélicas, e bem ciente que escrevo contra a corrente sem ter a destreza e a resiliência de Sísifo, considero que, não obstante as suas múltiplas falhas, imperfeições e terríveis

\footnotetext{
${ }^{20}$ Parecendo ignorar que há situações temporárias, bem como, demonstrando uma total falta de crença nos progressos da ciência, não estatuindo quaisquer mecanismos de reavaliação periódica da medida.

${ }^{21}$ Como assertivamente enfatiza, TRABUCO, Cláudia - O Regime das Incapacidades e Respectivo Suprimento: perspectivas de reforma. [Em linha]. Lisboa: FDUNL. [Consult. 01 set. 2017]; Disponível em: www.fd.unl.pt/docentes docs/ma/ct MA 5013.doc, p. 12.

${ }^{22}$ Neste sentido, p. e., SAMPAIO, Maria Carvalho - Regime Jurídico das Incapacidades: novo instituto para a proteç̧ão dos idosos. [Em linha]. Revista Julgar. [Consult. 01 set. 2017]; Disponível em: http://julgar.pt, p. 5.

${ }^{23}$ Como assertivamente sublinha TRABUCO, Cláudia - O Regime das Incapacidades e Respectivo Suprimento: perspectivas de reforma. [Em linha]. Lisboa: FDUNL. [Consult. 01 set. 2017]; Disponível em: www.fd.unl.pt/docentes_docs/ma/ct_MA_5013.doc, p. 3.

${ }^{24}$ PEREIRA, André Gonçalo Dias - A Capacidade para Consentir: um Novo Ramo da Capacidade Jurídica. In: Comemorações dos 35 anos do Código Civil e dos 25 anos da Reforma de 1977 / Faculdade de Direito da Universidade de Coimbra. Coimbra: Coimbra Editora, 2004-2006, p. 201.

${ }^{25}$ COSTA, Marta - A Desejável Flexibilidade da Incapacidade das Pessoas Maiores de Idade. "Lusíada". Lisboa, n. ${ }^{\circ}$ 7, pp. 121/122.

${ }^{26}$ SAMPAIO, Maria Carvalho - Regime Jurídico das Incapacidades: novo instituto para a protecção dos idosos. [Em linha]. Revista Julgar. [Consult. 01 set. 2017]; Disponível em: http://julgar.pt, pp.3/4.
}

Revista de Direito Brasileira | Florianópolis, SC | v. 23 | n. 9 | p. 323-341 | Mai./Ago. 2019 
defeitos que gritavam por uma alteração legislativa e uma depuração das normas existentes que colmatasse as suas múltiplas insuficiências, o regime legal destituído não estava necessariamente condenado à revogação. Porque infelizmente era necessário. Porque a norma não podia ser interpretada como apátrida, mas inserida num determinado sistema, que contempla janelas hermenêuticas que apenas estavam encerradas por inépcia [preguiça] interpretativa. Assim, dizer que o incapaz era equiparado ao menor não significa despojá-lo da juridicidade, privando-o absolutamente do exercício de direitos. Porque, equipará-lo ao menor era reconhecer-lhe, nos termos do art. $127 .^{\circ}$, aptidão para a prática dos negócios jurídicos correntes da sua vida, que estejam ao alcance da sua capacidade, bem como convocar o disposto no n. ${ }^{\circ} 2$, do art. $1878 .^{\circ}$, diretamente aplicável ao incapaz, por remissão expressa no art. $139 .^{\circ}$, que lhes reconhece o direito à autonomia na organização da própria vida, tendo por base a sua ipseidade. Acresce que a cominação jurídica dos atos praticados pelo interdito/inabilitado era a anulabilidade, permitindo que aqueles participassem no comércio jurídico, celebrando os contratos que se lhe aprouvessem, sendo que, a posteriori e caso se justificasse, o tutor ou curador os poderia atacar quando os mesmos estivessem em dissonância com os interesses daqueles. Por fim, recordar a possibilidade de convocar toda a dimensão constitucional inerente à dignidade da Pessoa humana que permitia afastar algumas normas ignóbeis. Porque, se formos honestos na análise, mais do que constrangimentos jurídico-burocráticos, o escasso recurso aos meios de tutela previstos na lei resulta de os familiares terem outras vias para aceder ao património relevante do maior carente de acompanhamento ou do seu total desinteresse pelo seu devir.

Enfatizo este ponto porque a "desconsideração da autonomia pessoal da pessoa sujeita a estas medidas" 27 não era o seu fado nem teria de ser uma inevitabilidade.Não obstante a minha convicção o legislador altivo na sua legitimidade decidiu reformar o regime jurídico do maior incapacitado, incumbindo ao jurista oferecer a melhor interpretação que se pode extrair do seu texto, sem nunca esquecer que o cachimbo de Magritte efetivamente não é um cachimbo e a traição existe quer nas imagens quer nas letras.

\section{OS PRINCÍPIOS QUE NORTEIAM (DEVIAM NORTEAR) O REGIME JURÍDICO DO MAIOR ACOMPANHADO}

Se no início era o Verbo, a diáspora por um Instituto jurídico deve atentar inicialmente aos Princípios, porque são estes que determinam as premissas para a criação, a interpretação e a aplicação de um Direito mais justo. Com efeito, estes não apenas inspiram a norma posta como são o suporte axiológico de um ordenamento jurídico que pretende ser coerente com a sua própria pretensão de legitimidade e validade, direcionado para uma materialização ética de justiça. Porque, no dia em que o Direito não for a constante e perpétua vontade de dar a cada um o que é seu deixa de ser Direito. Dessarte, os Princípios

"vinculam o próprio legislador constituinte porque, colocando as suas decisões
normativas sob o signo da justiça, tem que se submeter à lógica dos princípios
legitimadores de que se reclama, [pelo que], não podem ser derrogados sem
perversão da ordem jurídica e do sentimento jurídico da comunidade"28.

Procurando densificar, os Princípios jurídicos são abstrações, concretizadas pelos intérpretes a partir das normas (jurídicas e sociais), da doutrina e da jurisprudência, em diálogo

\footnotetext{
${ }^{27}$ TRABUCO, Cláudia - O Regime das Incapacidades e Respectivo Suprimento: perspectivas de reforma. [Em linha]. Lisboa: FDUNL. [Consult. 01 set. 2017]; Disponível em: www.fd.unl.pt/docentes_docs/ma/ct_MA 5013.doc, p. 10.

${ }_{28}$ JUSTO, A. Santos - Introdução ao Estudo do Direito. 6. ${ }^{\circ}$ Ed. Coimbra: Coimbra Editora, 2012, p. 223, em diálogo com Baptista MACHADO.
}

Revista de Direito Brasileira | Florianópolis, SC | v. 23 | n. 9 | p. 323-341 | Mai./Ago. 2019 
com a substrato social e as idiossincrasias específicas dos sujeitos a quem as normas se destinam, procurando estruturar o ordenamento jurídico (pelo que, não compete ao jurista construir princípios; apenas ter a destreza de reconhecer a sua existência, dada a sua natureza pré-jurídica).

In casu, são princípios estruturantes do novíssimo regime jurídico, o princípio da autonomia,o princípio da necessidade, princípio da subsidiariedade, princípio da proporcionalidade, princípio do respeito pela dignidade da pessoa humana, princípio da igualdade e não discriminação, princípio da audição e participação do interessado e princípio do controlo judicial e intervenção do Ministério Público.

Assim, tendo por premissa a extrema importânciada autonomia "na medida em que a manutenção dessa liberdade de escolha e de alguma capacidade para reger a sua pessoa e os seus bens contribui para a preservação da saúde mental e do bem-estar do indivíduo" 29 , sempre que possível, não se deve coartar a liberdade do indivíduo de decidir pessoal e livremente sobre o seu devir, um espaço para a sua individualidade, consagrando na norma posta o direito à autodeterminação. Dessarte, o princípio da autonomia exige a participação e inclusão plena e efetiva na sociedade, a liberdade para realizar as suas próprias escolhas e o respeito pela vontade do visado(reconhecendo-se-lhe o direito a errar) e deve erigir-se como princípio estruturante, decorrente do direito ao livre desenvolvimento da personalidade, constitucionalmente tipificado, após a revisão de 1997, transversal atodo o sistema e presente em todos os seus momentos.

Corolário deste, o princípio da necessidade, da subsidiariedade e da proporcionalidade determina que uma medida de proteção só deve ser adotada quando necessária e, sempre que tal aconteça, entre a panóplia de medidas passíveis de serem convocadas, se opte pela menos gravosa.

Com efeito, a conjugação destes princípios ensina que, na determinação de uma das medidas de apoio, se deve privilegiar os meios mais informais e as intervenções menos intrusivas, apenas se legitimando a estatuição de limitações legais à capacidade de agir quando falhar ou inexistir o recurso aos deveres de proteção e acompanhamento próprio das relações familiares e de afetividade. Dessarte,

"a defesa das pessoas com capacidade diminuída deve efectuar-se com a menor restrição possível dos direitos fundamentais, mediante o recurso a instrumentos de protecção que permitam assegurar àquelas o máximo controlo sobre a sua vida" 30 .

Nestes casos, tendo por premissa o princípio da proporcionalidade, que encerra noseu conteúdo um sentido de justa medida e vincula o exercício do legislador, do aplicador das normas, bem como o exercício dos poderes por parte do acompanhante, tem como desígnio uma intervenção mínima e menos restritiva, procurando-se desenhar instrumentos à medida dos interesses do maior acompanhado, que é o centro do sistema, com garantia pela reserva da vida privada e familiar do maior acompanhado. Sublinhe-se, porque o óbvio nem sempre é evidente para todos, o Direito deve centrar-se na Pessoa (e não na dimensão patrimonial, como é ordinário na legislação coeva), sendo o respeito pela dignidade um metavalor do ordenamento jurídico.

Como, toda e qualquer decisão que envolva o maior acompanhado deve ter na sua génese o intransigente respeito peloprincípio do direito à dignidade da pessoa humana, enquanto valor ético-jurídico que, desde logo, é incompatível com interdições genéricas e automáticas, aplicadas por um juiz panfletário, que reproduz sentenças sem considerar a

${ }^{29}$ TRABUCO, Cláudia - O Regime das Incapacidades e Respectivo Suprimento: perspectivas de reforma. [Em linha]. Lisboa: FDUNL. [Consult. 01 set. 2017]; Disponível em: www.fd.unl.pt/docentes_docs/ma/ct_MA_5013.doc, p. 17.

${ }^{30}$ PINHEIRO, Jorge Duarte - As Pessoas com Deficiência como Sujeitos de Direitos e Deveres: incapacidades e suprimentos - a visão do Jurista. [Em linha]. Lisboa. [Consult. 01 set. 2017]; Disponível em: https://www.icjp.pt/sites/default/files/media/600-886.pdf, p. 12

Revista de Direito Brasileira | Florianópolis, SC | v. 23 | n. 9 | p. 323-341 | Mai./Ago. 2019 
individualidade da Pessoa em causa, exigindo-se um regime jurídico com uma amplitude que permita ao julgador determinar casuisticamente a extensão e os limites da incapacidade.

Como, quer a legislação quer a aplicação do Direito, devem ter presentes o princípio da igualdade e não discriminação, conforme expressamente estabelece a Convenção das Nações Unidas, trazendo à colação a obrigação de não discriminação com fundamento na deficiência como regra fundamental e agregadora dos direitos fundamentais nela consagrados (art. 5. ${ }^{\circ}$ ), corolário do respeito pela diferença como parte da diversidade humana, tantas vezes ignorado no bas-fond da realidade.

Nem sempre devidamente valorados, quero enfatizar aqui os princípios da audição e participação do interessado e do controlo judicial e intervenção do Ministério Público ${ }^{31}$, que me parecem essenciais. Dessarte, qualquer decisão que envolva um maior acompanhado exige a sua participação ativa, sendo exigível que a sua voz seja escutada, existindo um controlo jurisdicional efetivo das intervenções de terceiros e a obrigatoriamente do processo passar por um severo crivo do Ministério Público, cuja mais nobre função é a venia debilium, a quem deve ser concedidos os meios necessários para que a letra da lei não sejam palavras mortas. Como reiteradamente acontece e, temo, este caso não seja a exceção.

\section{ANÁLISE CRÍTICA À NORMA POSTA}

Tendo por fontes imediatas a Convenção das Nações Unidas sobre os Direitos da Pessoa com Deficiência e o seu Protocolo Adicional, ambos adotados em Nova Iorque, a 30 de março de 2007, aprovados pelas Resoluções da Assembleia da República n. . 56/2009 e n. 57/2009, de 7 de maio de 2009 e a Recomendações do Conselho da Europa ${ }^{32}$, em particular à Recomendação $n^{\circ}$. R(99)4 do Conselho da Europa, relativa aos Princípios Respeitantes à Proteção Jurídica dos Maiores Incapazes, a Lei n. ${ }^{\circ}$ 49/2018, de 14 de agosto, foi instituído o regime jurídico do maior acompanhado, derrogando-se o regime vigente.

Concomitantemente com as fontes jurídicas, a novel legislação carrilou para o ordenamento jurídico o latejar da realidade, patentena nova mentalidade de franjas da sociedade sobre a pessoa com deficiência e a consciência da necessidade de as integrar na sociedade. Ademais, foram determinantesos avanços da medicina e o consequente aumento da esperança média de vida e o decorrente aumento das limitações naturais e das doenças neurodegenerativas, o resultado da evolução socioeconómica do país com uma elevação muito considerável do nível de vida, o estabelecimento de um Estado Social e a evolução da psiquiatria, que hoje interpreta a deficiência como um conceito em evolução que resulta da interacção entre pessoas com incapacidades e barreiras comportamentais e ambientais que impedem a sua participação plena e efectiva na sociedade em condições de igualdade com as outras pessoas ${ }^{33}$.

Um prelúdio para a nomenclatura adotada: entre as possibilidades, seja incapacitado,maior incapaz, pessoa com deficiência, maior assistido, maior protegido, adultos vulneráveis ${ }^{34}$, pessoas com necessidades especiais ${ }^{35}$ oupessoa com capacidade diminuída, o legislador optou pela denominação maior acompanhado, inspirado no direito alemão, o que merece efusivo aplauso. Mais. Que este seja o primeiro passo para expurgar do ordenamento jurídico lusitano a panóplia de designações estigmatizantes que ainda proliferam nas normas.

\footnotetext{
${ }^{31}$ Sobre os desafios que o novo regime oferece ao Ministério Público, vide PAZ, Margarida - O Ministério Público e o Novo Regime do Maior Acompanhado. Lisboa, CEJ, 2019, pp. 114 e ss.

${ }^{32}$ Cujas recomendações têm um papel muito relevante, apesar de não ser fonte formal de Direito.

${ }^{33}$ Preâmbulo da Convenção dos Direitos das Pessoas com Deficiência.

${ }^{34}$ Assim, a Resolução do Parlamento Europeu, de 1 de junho de 2017, que contém recomendações à Comissão sobre a proteção dos adultos vulneráveis (2015/2085(INL))

${ }^{35}$ Por exemplo, na Lei n. ${ }^{\circ} 27 / 2007$, de 30 de julho.
}

Revista de Direito Brasileira | Florianópolis, SC | v. 23 | n. 9 | p. 323-341 | Mai./Ago. 2019 
Dessarte, quando indagamos a etimologia, acompanhar significa seguir na mesma direção que o outro, espelhando bem o que se deseja com este novo Instituto ${ }^{36}$.

Regressando à nossa rota, sem ambiguidades, este regime jurídico elimina os Institutos da Interdição e da Inabilitação, desenhando a transição de um modelo de substituição para um modelo de acompanhamento ${ }^{37}$ aplicável a todos aqueles que por razões de saúde, deficiência, ou pelo seu comportamento, estejam impossibilitados de exercer, plena, pessoal e conscientemente, os seus direitos ou de, nos mesmos termos, cumprir os seus deveres (art. 138. ${ }^{\circ}$ ).

Assim, para que seja possível determinar uma medida de acompanhamento, exige-se a verificação cumulativa de duas condições: (i) que o sujeito, por doença, por deficiência, ou pelo seu comportamento, (ii) esteja impossibilitado, plena, pessoal e conscientemente, de exercer os seus direitos.

Foi feliz o legislador em separar as razões de saúde da questão da deficiência, combatendo o preconceito que ainda interpreta a pessoa com deficiência como um doente. Como, subscrevo a opção legislativa de elencar três grandes arquétipos, permitindo, quer à doutrina quer à jurisprudência, a sua densificação e a concretização da norma a patologias específicas.

Obviamente que a solução não é imune a críticas e inquietações. Até porque o mundo da semântica é sempre passível de censura, não fossem as palavras significado e também significante. Assim, o substantivo doença deverá interpretar-se de acordo com a terminologia adotada pela Organização Mundial de Saúde ou, antes, num sentido mais corriqueiro? Quais as deficiências que o legislador tem em mente? Devemos cooptar a definição que resulta da Convenção ${ }^{38}$ ? Como, a menção a comportamento parece indiciar uma atitude deliberada e consciente.

Não obstante, saúda-se a opção do legislador: $a b$ initio, quando exterminou a enumeração exemplificativa constante da norma revogada atacou o carácter estigmatizante que atribuía a estas patologias; por outro lado, este Instituto pode "abranger mais situações do que as quepossibilitavam a interdição ou a inabilitação"39. Assim, são passíveis de se subsumir ao elemento subjetivo da norma patologias como as que já estavam previstas, quer para a interdição quer para a inabilitação, bem como quaisquer outras com identidade de razões.

Dessarte, o conceito de doença tem suficiente elasticidade para englobar patologias como paralisia cerebral, coma, avc, inter alia. No que concerne a deficiência, esta poderá abranger situações de doença neurológica (Demência, Alzheimer, Parkinson), doença mental (Esquizofrenia, Bipolaridade, Psicose, Síndrome depressivo) ou de deficiência mental ou intelectual (Síndrome de Down, Autismo, Oligofrenia, entre outras).

De crucial importância é o facto de, contrariamente ao regime anterior, inferir-se do disposto no art. 899..$^{\circ}$ do $\mathrm{CPC}$, que o exame pericial não é obrigatório, só sendo exigível quando determinado pelo juiz. Não obstante, por eidéticas motivações, a importância deste exame não deve ser escamoteada, sendo, as mais das vezes, imprescindível.

\footnotetext{
${ }^{36}$ Em sentido adverso, no seu Parecer sobre a Proposta de Lei o MP considera que "o substantivo acompanhante tem também uma conotação muito comum, de cariz sexual, ou seja, pessoa que vende os seus serviços sexuais sem se expor na rua, geralmente com negociação ou marcação, e é desconhecida do nosso ordenamento jurídico"

${ }^{37}$ Em linha com o que "tem sido este o sentido seguido pela generalidade dos ordenamentos jurídicos europeus e pelos instrumentos de direito internacional, sendo chegada a hora da nossa ordem jurídica dar o passo no caminho da harmonização, colhendo a sua lição" (SAMPAIO, Maria Carvalho - Regime Jurídico das Incapacidades: novo instituto para a protecção dos idosos. [Em linha]. Revista Julgar. [Consult. 01 set. 2017]; Disponível em: http://julgar.pt, p. 2).

${ }^{38}$ As pessoas com deficiência incluem aqueles que têm incapacidades duradouras físicas, mentais, intelectuais ou sensoriais, que em interacção com várias barreiras podem impedir a sua plena e efectiva participação na sociedade em condições de igualdade com os outros (art. 1. ${ }^{\circ}$ da Convenção sobre os Direitos das Pessoas com Deficiência).

${ }^{39}$ BELEZA, Maria dos Prazeres - Brevíssimas Notas sobre a Criação do Regime do Maior Acompanhado, em substituição dos Regimes da Interdição e da Inabilitação - Lei n. ${ }^{a}$ 19/2018, de 14 de agosto. Lisboa: CEJ, 2019, p. 18.
} 
Por fim, no que respeita a comportamentos, trazemos à colação as velhas categorias conhecidas da prodigalidade, abuso de bebidas alcoólicas ou estupefacientes, etc.

Mas, como deixei escrito, apenas se justifica uma reação jurídica quando, independentemente da causa, esta mitiga a capacidade do sujeito de atuar juridicamente. Assim, é crucial e imprescindível para a determinação da medida de acompanhamento a existência de uma "qualquer limitação às faculdades intelectuais e mentais, que afectem a inteligência, a percepção ou a memória, ou que afectem a formação e manifestação da vontade" ${ }^{40}$, a qual impossibilite aquele sujeito de, pessoal e livremente, exercer os seus direitos.

Pela pertinência da decisão, que restringeou anula a capacidade de agir de uma pessoa, a determinação de uma medida de acompanhamento passa pelo crivo judicial, sendo exigível a audição pessoal e direta do beneficiário $\left(\operatorname{art} .139 .^{\circ}\right)^{41}$, mesmo que, para isso, o juiz tenha dese deslocar onde se encontre esse beneficiário (art. 897..$^{\circ}$ n. ${ }^{\circ} 2 ; c f$. art. $139 .^{\circ}$, n. $\left.^{\circ} 1, \mathrm{CC}\right)^{42}$, e visa assegurar o seu bem-estar, a sua recuperação, o pleno exercício de todos os seus direitos $e$ o cumprimento dos seus deveres, salvo as exceções legais ou determinadas por sentença (n. ${ }^{\circ} 1$, do art. $\left.1400^{\circ}\right)$.Se subscrevo o sentido, parece-me que a pena do legisladordixi plus quam voluit e resvalou para um reacionário modelo médico, quando elege como valor fundamental do acompanhamento a recuperação do beneficiário ${ }^{43}$, ignorando olimpicamente a temática da inclusão.

Ab initio, sublinhe-se a supletividade deste Institutoque não tem lugar sempre que o seu objetivo se mostre garantido através dos deveres gerais de cooperação e de assistência que no caso caibam (n. ${ }^{\circ}$, do art. $140 .^{\circ}$ ), as chamadas medidas informais de acompanhamento. Se a opção é filosoficamente correta e o legislador confia que o princípio da solidariedade familiar é bastante para garantir a eficaz tutela do maior que precisa de acompanhamento, toda a dimensão burocrática do acompanhamento e a urgência de estatuir um regime para o cuidador informal, bem como as múltiplas circunstâncias em que aquele que precisa de proteção é vilipendiado por quem tem o dever de o proteger, temo que o devir da realidade faça letra morta do texto legal.

Igualmente pertinente, e especificamente estatuído, para contrariar a unanimidade das críticas ao regime revogado, no qual o leque de pessoas com legitimidade para requerer a interdição era demasiado restrito, porquanto, entre outros pecados, impedia o próprio interessado de agir, o regime atual sagra a possibilidade de o acompanhamento ser requerido pelo próprio ou, mediante autorização deste, pelo unido de facto, bem como, na esteia do regime anterior, o seu cônjuge, qualquer parente sucessível ou, independentemente de autorização, pelo Ministério Público (art. 141. ${ }^{\circ}$ ). A consagração da possibilidade de ser o próprio beneficiário a requerer uma medida de acompanhamento é eidética, ainda que gere estupefação nos mais distraídos. Dessarte, tendo consciência da perda das suas capacidades volitivas, o interessado poderá, ele próprio, iniciar o processo ou autorizar outros que o façam por si. Mas, e caso não o faça, o tribunal pode suprir a autorização do beneficiário quando, em face das circunstâncias, este não a possa livre e conscientemente dar, ou quando para tal considere existir um fundamento atendivel (n. ${ }^{\circ} 2$, do art. $\left.141 .^{\circ}\right)$.

\footnotetext{
${ }^{40}$ NEVES, Alexandra - O Estatuto dos "Cidadãos Invisíveis": o longo caminho para a plena cidadania das pessoas com deficiência. [Em linha]. Lisboa: Universidade Autónoma de Lisboa. [Consult. 01 jul. 2017]; Disponível em: http://repositorio.ual.pt, p. 298.

${ }^{41}$ Refira-se que a audição pessoal e direta do beneficiário visa averiguar a sua situação e ajuizar das medidas de acompanhamento mais adequadas, sendo realizada pelo juiz, com a assistência do requerente, dos representantes do beneficiário e do perito ou peritos, quando nomeados, podendo qualquer dos presentes sugerir a formulação de perguntas, sendo lícito o juiz determinar que parte da audição decorra apenas na presença do beneficiário (art. $898 .^{\circ}$, do CPC).

42 No mesmo sentido, SOUSA, Miguel Teixeira de - O Regime de Acompanhamento de Maiores: alguns aspetos processuais. Lisboa: CEJ, 2019, p. 45.

${ }^{43}$ Não estou isolado nesta crítica, sendo igualmente enfatizada pelo Parecer sobre a Proposta de Lei n. ${ }^{\circ}$ 110/XII, do Ministério Público.
}

Revista de Direito Brasileira | Florianópolis, SC | v. 23 | n. 9 | p. 323-341 | Mai./Ago. 2019 
Mais, como ficou escrito, se uma das assertivas críticas assacadas ao regime anterior era a urgência de alargar o núcleo das pessoas com legitimidade para interpor estas ações, o alargamento efetuado peca por defeito, por escamotear legitimidade para intentar o processo às pessoas com as quais o maior que necessita de acompanhamento vive em economia comum, ao afilhado, às pessoas com quem mantém sólidas relações de afetividade e às instituições à guarda das quais eventualmente possa estar.

O processo inicia-se com o pedido de suprimento da autorização do beneficiário que pode ser cumulado com o pedido de acompanhamento (nos casos em que não é o próprio), e no requerimento dever-se-á

a) alegar os factos que fundamentam a sua legitimidade e que justificam a proteção do maior através de acompanhamento; b) requerer a medida ou medidas de acompanhamento que considere adequadas; $c$ ) indicar quem deve ser o acompanhante e, se for caso disso, a composição do conselho de família; d) indicar a publicidade a dar à decisão final; e) juntar elementos que indiciem a situação clínica alegada (art. 892. ${ }^{\circ}$, do CPC).

Sublinhe-se que o processo de acompanhamento de maior tem carácter urgente, aplicando-se-lhe, com as necessárias adaptações, o disposto nos processos de jurisdição voluntária no que respeita aos poderes do juiz, ao critério de julgamento e à alteração das decisões com fundamento em circunstâncias supervenientes(art. $891 .^{\circ}$, do CPC).

No que concerne ao conteúdo do acompanhamento, consagrou-se um modelo flexível e casuístico, tendo por premissa o princípio da intervenção mínima ( o acompanhamento limita-se ao necessário), cumprindo o estatuído no n. ${ }^{\circ}$, do art. $18 .^{\circ}$, da CRP, devendo optar-se pela solução da alternativa menos restritiva, sem que o Tribunal esteja adstrito ao peticionado, de entre o elenco estatuído na lei, a saber:

a) Exercício das responsabilidades parentais ou dos meios de as suprir, conforme as circunstâncias;

b) Representação geral ou representação especial com indicação expressa, neste caso das categorias de atos para que seja necessária;

c) Administração total ou parcial de bens;

d) Autorização prévia para a prática de determinados atos ou categorias de atos;

e) Intervenções de outro tipo, devidamente explicitadas.

Pela sua pertinência, escalpelizo a norma. Assim:

(i) Exercício das responsabilidades parentais; quando esta medida seja determinada pelo Tribunal, solução que apenas se justificará nos casos de grave incapacidade, aparentemente [porque a configuração concreta desta medida permite ambiguidades], repristinamos o regime anterior, sendo o maior acompanhado equiparado ao menor, funcionando o acompanhante como se de um tutor se tratasse, mantendo-se o caráter paternalista do passado, refletindo a inadmissível conceção da pessoa com deficiência como sendo uma criança. Deixado o reparo, se numa primeira leitura esta disposição vai ao arrepio das premissas que legitimaram este novo Instituto, o voluntarismo não pode fazer-nos esquecer de caminhar com os pés no chão, pelo que, nas nossas análises, não podemos escamotear que há causas que aniquilam absolutamente a capacidade de querer e entender, afigurando-se a representação jurídica como uma inevitabilidade. Para proteção da pessoa com deficiência, porque, importa nunca esquecer, é tão abjeto impedir alguém com capacidade de querer e entender para agir juridicamente como dar capacidade jurídica de exercício a quem carece daquela.

(ii) Representação geral ou representação especial com indicação expressa, neste caso, das categorias de atos para que seja necessária; se a metáfora me é permita, nesta Revista de Direito Brasileira | Florianópolis, SC | v. 23 | n. 9 | p. 323-341 | Mai./Ago. 2019 
circunstância, é construindo um fato à medida do acompanhado, uma metamorfose do pret-àporter para a alfaiataria, em que as medidas de acompanhamento são desenhadas especificamente para aquele sujeito, tendo por premissa a sua ipseidade e idiossincrasia. Também aqui existe o Instituto da representação (que, com as necessárias adaptações, segue o regime da tutela), mas esta não é geral é absolutamente castradora da capacidade de determinação do maior acompanhado, cingindo-se a determinados atos jurídicos específicos, os chamados hard cases;

(iii) Administração total ou parcial de bens; o Instituto da administração de bens, previsto e estatuído nos art. $1967 .^{\circ}$ e ss., está consolidado no nosso ordenamento jurídico não oferecendo, neste contexto, quaisquer especificidades. Atrai-me a solução.Desde há muito que se sabe que a roda é redonda e esta tentação doutrinal e legislativa de reinventar o que já foi inventado é pouco saudável: se existem Institutos consolidados, renovar pelo simples prazer da novidade gera entropias no sistema, profundamente desaconselháveis;

(iv) Autorização prévia para a prática de determinados atos ou categorias de atos; esta é, porventura, a medida de apoio que melhor espelha a filosofia subjacente ao novo regime. In casu, é o maior que exerce pessoalmente os seus direitos, que se vincula juridicamente, sendo assistido pelo acompanhante em determinadas e específicas situações jurídicas, respeitando-se assim a sua autonomia e liberdade de agir, ao mesmo tempo que o protegemos de eventuais atuações abusivas de terceiros, lesivas dos seus legítimos direitos;

(v) Intervenções de outro tipo, devidamente explicitadas. Por fim, a norma oferece expressamente ao julgador a liberdade [que teoricamente já tinha mas era sumptuosamente ignorada], para tecer situações específicas tendo como premissa a idiossincrasia do maior em causa, estatuindo um regime legal casuístico que se adapte a determinada situação específica. $\mathrm{O}$ enigma é perceber se ao julgador vão ser concedidos meios materiais e humanos para que o desejo legislativo seja uma realidade nas barras dos nossos tribunais.

De crucial importância é o facto de que, independentemente da medida de acompanhamento, os atos de disposição de bens imóveis carecem sempre de autorização judicial prévia e específica (n. ${ }^{\circ} 3$, do art.145..$^{\circ}$ ), o que se justifica para mitigar as recorrentes situações em que abusivamente se dilapida o património da pessoa cujas capacidades estão diminuídas. Por razões semelhantes, também o internamento, seja em unidade hospital seja em lares e residências, depende de autorização expressa do tribunal (art. 148. ${ }^{\circ}$ ).

De especial acuidade, embora prolixo, porque a regra já se devia inferir do texto constitucional e dos diplomas internacionais ratificados pelo Estado, consagra-se como regra a liberdade para o exercício dos direitos pessoais e para a celebração dos negócios da vida corrente. Sublimando, neste contexto, que a insuscetibilidade de exercício dos direitos pessoais era uma solução adversa ao princípio da dignidade da pessoa que carece de acompanhamento incompatível com o direito ao livre desenvolvimento da sua personalidade, ambos com guarida constitucional, só se admitindo esta limitação casuística e fundamentadamente. Dessarte, o que neste contexto se tutela é a própria Pessoa, uma vez que em debate estão direitos estritamente pessoais, que não se comunicam ao seu representante e cuja sonegação retiraria o estatuto de cidadania ao maior acompanhado.

O legislador, quiçá influenciado pelo caso $\mathrm{Kevin}^{44}$, foi bem-intencionado quando prescreveuque o acompanhante mantém um contacto permanente com o acompanhado, devendo

\footnotetext{
${ }^{44}$ A triste história é-nos oferecida por CORDEIRO, António Menezes - Da situação jurídica do maior acompanhado. Estudo de política legislativa relativo a um novo regime das denominadas incapacidades dos maiores. [Em Linha]. Lisboa. [Consult. Abril de 2018]. Disponível em: http://www.smmp.pt/wp-content/uploads/Estudo_MenezesCordeiroPinto-MonteiroMTS.pdf, pp. 56/57.
}

Revista de Direito Brasileira | Florianópolis, SC | v. 23 | n. 9 | p. 323-341 | Mai./Ago. 2019 
visitá-lo, no mínimo, com uma periodicidade mensal, ou outra periodicidade que o tribunal considere adequada (n. ${ }^{\circ} 2$, do art.146. $\left.{ }^{\circ}\right)^{45}$. Sucede que, como nos ensina a vox populi, de boas intenções está cheia a primeira parte da Divina Comédia de Dante e nem a prescrição de uma periodicidade obrigatória de visitas ao acompanhado é garantia do seu cumprimento, como o seu cumprimento formal não garante que o acompanhante exerce com a diligência de um bonus pater familiae o poder funcional de que foi incumbido. Aliás, basta aferir do homérico insucesso de uma estatuição análoga, cujos sujeitos são as crianças institucionalizadas para compreender a ineficácia da previsão legal.

De colossal importância na reforma é o facto de o acompanhante (ou acompanhantes, porque podem ser designados vários, com diferentes funções, especificando-se as atribuições de cada um) ser escolhido pelo acompanhado ou pelo seu representante legal, só supletivamente recaindo em pessoa designada pelo Tribunal, sem que este esteja adstrito a uma ordenação prédeterminada, podendo nomear a pessoa que melhor salvaguarde o imperioso interesse do beneficiário ( $c f$., art. 143. ${ }^{\circ}$ ), vigorando no seu exercício o princípio da gratuitidade,sem prejuízo da alocação de despesas, consoante a condição do acompanhado e a do acompanhante, ficando o acompanhante com a obrigação de prestar contas ao acompanhado e ao tribunal, quando cesse a sua função ou, na sua pendência, quando assim seja judicialmente determinado (art. $151 .^{\circ}$ ).

Muito importante foi a estatuição da possibilidade de um mandato para incapacidade futura $^{46}$, "isto é, com a possibilidade de qualquer pessoaprevenir uma eventual necessidade futura, indicando, desde logo, quem a acompanhará oua representará, caso isso venha a verificarse, e que poderes lhe atribui" 47 , através de um mandato para gestão dos seus interesses, com ou sem poderes de representação $\left(n .^{\circ} 1\right.$, do art. $\left.156 .^{\circ}\right)$. Não obstante esta norma nada oferecer de novo e está linha, com o que fez o Estado Português quando, em 2012, regulou as diretivas antecipadas de vontade nas modalidades de testamento vital e do procurador de cuidados de saúde, através da Lei n. ${ }^{\circ}$ 25/2012, de 16 de julho, pela sua pertinência, a possibilidade de o acompanhado designar o seu acompanhante exige uma ponderação adicional.

Assim, se é indispensável que a voz da pessoa com deficiência seja escutada, e não apenas ouvida, se se impõe reconhecer-lhe legitimidade para requerer as medidas que, fundadamente, considere necessárias para a sua proteção, e que se lhe reconheça capacidade para nomear alguém para a representar, esta escolha não possa ser acatada levianamente, expondo o acompanhado a toda uma panóplia de explorações.

Com efeito, é preciso sempre imenso tato quando se quer simplificar o complexo: se reclamo legitimidade para escolher quem vai representar a pessoa com deficiência, a ingenuidade, o economicismo, ou a leviandade não podem escamotear que o mandato para incapacidade futura poderá não ser nem inócuo, nem imaculado. Destarte, se uma mera procuração, ainda que reconhecida notarialmente, poderia ser uma solução, esta é profusamente desaconselhada, porquanto expõe a pessoa com deficiência a uma heterogeneidade de comportamentos desviantes. Porque se a ingenuidade no jurista é confrangedora, no legislador é imoral: com a mesma candura que encontramos aqueles que aceitam ser representantes de pessoas com capacidade diminuída por puro altruísmo, com imensos prejuízos próprios, existem aqueloutros sempre despertos para utilizar em seu proveito as debilidades alheias, pelo que um processo meramente administrativo seria inaceitável. Por tudo, a nomeação de um representante deverá sempre passar pelo cunho judicial, de forma a aferir sobre as benignas intenções do

\footnotetext{
${ }^{45}$ Não estranha, portanto, que a norma seja inspirada no $§ 1793$ do BGB.

${ }^{46}$ Sobre este, Menezes Cordeiro não esconde as dúvidas que o mesmo lhe suscita (CORDEIRO, António Menezes Da situação jurídica do maior acompanhado. Estudo de política legislativa relativo a um novo regime das denominadas incapacidades dos maiores. [Em Linha]. Lisboa. [Consult. Abril de 2018]. Disponível em: http://www.smmp.pt/wp-content/uploads/Estudo_Menezes-CordeiroPinto-MonteiroMTS.pdf, p. 108).

${ }^{47}$ MONTEIRO, António Pinto -Das incapacidades ao Maior Acompanhado-Breve Apresentação da Lei $49 / 2018$. Lisboa: CEJ, 2019, p. 31.
} 
requerido ${ }^{48}$. Em consonância com o pensamento exposto, ainda que exista um mandato com vista a acompanhamento futuro, no momento em que é decretado o acompanhamento, o tribunal aproveita o mandato, no todo ou em parte, e tem-no em conta na definição do âmbito da proteção e na designação do acompanhante, sendo lícito fazer cessar o mandato quando seja razoável presumir que a vontade do mandante seria a de o revogar (art. 156..$^{\circ}$.

No que concerne ao seu estatuto, o acompanhante exerce as suas funções gratuitamente (sem prejuízo da alocação de despesas), deve abster-se de agir em conflito de interesses com o acompanhado e pode ser removido e exonerado, bem como pedir escusa, com os fundamentos previstos no artigo $1934 .^{\circ}$ ou ser substituído, a seu pedido, ao fim de cinco anos, com exceção do cônjuge, os descendentes ou os ascendentes não podem escusar-se ou ser exonerados ${ }^{49}$, exceto, no caso dos descendentes, se existirem outros descendentes igualmente idóneos (art. 144. ${ }^{\circ}$ ).

A novel legislação consagra ainda o dever de que a determinação das medidas de acompanhamento não sejamad eternum, estatuindo-se a obrigatoriedade de revisão periódica com uma periodicidade, mínima, de cinco anos (art. 155. ${ }^{\circ}$ ), solução que se subscreve. Com efeito, quer pelos avanços da medicina quer por uma pletora de outras circunstâncias, o facto de um sujeito, num determinado momento, estar inapto para exercer pessoal e livremente os seus direitos não significa que deva ser ostracizado para sempre do comércio jurídico. Como, da revisão periódica poderá resultar, por excesso ou por defeito, que a medida determinada já não corresponde ao concreto interesse do maior acompanhado (no mesmo sentido, em qualquer altura do processo, podem ser determinadas as medidas de acompanhamento provisórias e urgentes, necessárias para providenciar quanto à pessoa e bens do requerido, conforme dispõe o n. ${ }^{\circ}$, do art. $\left.139 .^{\circ}\right)$. Acresce que, o acompanhamento cessa ou é modificado mediante decisão judicial que reconheça a cessação ou a modificação das causas que o justificaram (art. 149.'), tendo legitimidade para pedir a cessação ou modificação do acompanhamento o acompanhante ou qualquer uma das pessoas referidas no $n^{\circ} 1$ do artigo $141 .^{\circ}$

Uma referência ainda para a necessidade de ponderar a publicidade a dar às medidas de acompanhamento, tendo presente o caráter estigmatizante deste processo (embora, sem escamotear que o maior acompanhado dialoga juridicamente com terceiros, cujas expectativas jurídicas não podem ser ignoradas), tendo ficado estatuído, no art. 153. ${ }^{\circ}$, que a publicidade a dar ao início, ao decurso e à decisão final do processo de acompanhamento é limitada ao estritamente necessário para defender os interesses do beneficiário ou de terceiros, sendo decidida, em cada caso, pelo tribunal, sem prejuízo de quando o interesse do beneficiário o justifique, o tribunal pode dirigir comunicações e ordens a instituições de crédito, a intermediários financeiros, a conservatórias do registo civil, predial ou comercial, a administrações de sociedades ou a quaisquer outras entidades (art. 894. ${ }^{\circ}$, do CPC).

\section{CONCLUSÃO}

Repito amiúde que o mundo não pula e avança nas mãos de um Decreto-Lei, pelo que permita-se-me começar a conclusão com um truísmo: não é através da atividade legiferante que se solucionam os problemas das pessoas que precisam de acompanhamento. $\mathrm{O}$ que não significa afirmar a impotência da lei. Dessarte, há muito que aderi ao pensamento de Lawrence LESSIG,explicitamente quando o A. divide a regulação em leis, normas sociais, arquitetura

\footnotetext{
${ }^{48}$ Em sentido não totalmente coincidente, Raúl ALVES defende a intervenção de um notário ou outra entidade pública (ALVES, Raúl Guichard - Alguns Aspectos do Instituto da Interdição. In: Interdição e Inabilitação. [Em linha]. Lisboa: CEJ. [Consult. 01 dez. 2017]; Disponível em: www.cej.mj.pt/cej/recursos/ebooks/civil/Interdicao_inabilitacao.pdf, p. 119).

${ }^{49}$ A solução não deve aceitar-se acriticamente: não é desejável que alguém, contra a sua vontade e desejo, seja condenado a ser acompanhante, circunstância que pode inquinar o desempenho da sua missão.
} 
(natureza) e mercado, identificando-os como os constrangimentos que determinam o nosso comportamento social. Porque, efetivamente, o Direito é muito mais do que Leis; se estas são cruciais, porque expressam os valores de uma comunidade, porque sãoconstruídas através da legitimidade democrática e beneficiam do jus imperii, o Direito não se pode reduzir a uma coleção de diplomas. Com efeito, para regular uma dada sociedade, a par da lei, precisamos de uma normatividade imposta pela comunidade que vai nortear, limitando ou convidando a determinados comportamentos, por temer as cominações impostas pela sociedade. A arquitetura (natureza), demasiadas vezes, é o meio mais eficaz para regular comportamentos, como o mercado, através dos preços, condiciona os nossos comportamentos e impele-nos - ou repelo-nos - para determinada direção.

Assumido a premissa, urge reconhecer que, com falhas e imprecisões que nem Homero foi imune, o novo regime do maior acompanhado é uma pedra angular para o reconhecimento da dignidade da pessoa com deficiência, por aumentar as suas possibilidades de participar no tráfego jurídico, tecido com respeito com os princípios constitucionais e de direito internacional.

Dessarte, quer as pessoas com deficiência quer outros maiores que estejam incapacitados de exercer pessoal e livremente os seus direitos têm atualmente ao seu dispor um regime jurídico que, sem escamotear a sua dimensão protetora, permite-lhes agir juridicamente no limite da sua capacidade de entendimento e compreensão, reconhecendo-se-lhes o direito a errar.

Mas, porque o otimismo crónico é realmente irritante, sem niilismo, urge ter presente que há muitas pedras para guardar até construirmos um castelo que proteja eficazmente as pessoas com deficiência. Desde logo, com a inequívoca crise das Famílias (num tempo em que o conceito está em plena reformulação), exige-se uma intervenção firme e assertiva dos Poderes Públicos, nomeadamente dos serviços de Segurança Social, bem como trazer à colação as associações privadas $^{50}$, cujos contributos não podemos ignorar. Por outro lado, se encontramos na norma posta o direito à autodeterminação, a lei deixa espaços de sombra e está [quiçá excessivamente] dependente das boas práticas judiciais, tendo-se consagrado um papel crucial para o juiz, sem que encontremos na praxis os meios de que o tribunal vai carecerá para exercer a sua Missão.

Ensina o provérbio africano, é preciso uma aldeia para educar uma criança: arrisco afirmar que, para proteger as pessoas com deficiência, é preciso um País inteiro...

\section{BIBLIOGRAFIA}

- AlbuQuerque, Patrícia e RAMOS, Susana. A Sexualidade na Deficiência Mental Profunda: um estudo descritivo sobre atitudes de pais e educadores. [Em linha]. Lisboa: Portal dos Psicólogos. [Consult. 01 set. 2017]; Disponível em: www.psicologia.pt/artigos/textos/A0367.pdf;

- ALVES, Raúl Guichard. Alguns Aspectos do Instituto da Interdição. In: Interdição e Inabilitação. [Em linha]. Lisboa: CEJ. [Consult. 01 dez. 2017]; Disponível em: www.cej.mj.pt/cej/recursos/ebooks/civil/Interdicao_inabilitacao.pdf;

\section{- ARAUJO, Luiz David. A Proteção Constitucional das Pessoas Portadoras de Deficiência.} Brasília: Coordenadoria Nacional para a Integração da Pessoa Portadora de Deficiência, 1997;

\footnotetext{
50 Que mais uma vez foram olimpicamente ignoradas na elaboração desta legislação, em desrespeito com as obrigações assumidas pelo Estado, mormente as previstas no n. ${ }^{\circ} 3$, do art. $4 .^{\circ}$ da Convenção, que expressamente determina que no desenvolvimento e implementação da legislação e políticas para aplicar a presente Convenção $e$ em outros processos de tomada de decisão no que respeita a questões relacionadas com pessoas com deficiência, os Estados Parte devem consultar-se estreitamente e envolver activamente as pessoas com deficiências, incluindo as crianças com deficiência, através das suas organizações representativas.
}

Revista de Direito Brasileira | Florianópolis, SC | v. 23 | n. 9 | p. 323-341 | Mai./Ago. 2019 
- BELEZA, Maria dos Prazeres.Brevíssimas Notas sobre a Criação do Regime do Maior Acompanhado, em substituição dos Regimes da Interdição e da Inabilitação - Lei n. 19/2018 de 14 de agosto. Lisboa: CEJ, 2019, pp 13-22;

- BUBLITZ, Michelle Dias. Pessoa com Deficiência e Teletrabalho: um olhar de viés da inclusão social: reflexões à luz do valor social do trabalho e da fraternidade. Porto Alegre: Livraria do Advogado Editora, 2015;

- CORDEIRO, António Menezes.Da situação jurídica do maior acompanhado. Estudo de política legislativa relativo a um novo regime das denominadas incapacidades dos maiores. [Em Linha]. Lisboa. [Consult. Abril de 2018]. Disponível em: http://www.smmp.pt/wpcontent/uploads/Estudo_Menezes-CordeiroPinto-MonteiroMTS.pdf ;

- CARVAlHO, Suzy e FREITAS, Ana. Pessoa com Deficiência Intelectual ante a Lei 13.146/15. "Revista da AGU”. Brasília-DF. v. 17, n. 1, pp. 313-334;

- COSTA, Marta.A Desejável Flexibilidade da Incapacidade das Pessoas Maiores de Idade. "Lusíada". Lisboa, n. ${ }^{\circ}$ 7, pp. 109-162;

- - DHANDA, Amita.Construindo um Novo Léxico dos Direitos Humanos: convenção sobre os direitos das pessoas com deficiência. "Revista Internacional de Direitos Humanos". São Paulo, a.5, n.8, pp. 42-59;

- FERNANDES, Ana Paula e DENARI, Fátima.Pessoa com Deficiência: estigma e identidade. "Revista FAEEBA". Salvador, v. 26, n. 50, pp. 77-89;

- FONTES, Fernando.Pessoas com Deficiência em Portugal. Lisboa: FFMS, 2016.

- LIMA, Andrei e DORNELLES, Daniélle.Dignidade-Vulnerabilidade Versus DignidadeLiberdade - um estudo crítico do estatuto da pessoa com deficiência a partir do conceito de dignidade da pessoa humana. [Em linha]. Lima: Facultad de Derecho de la Pontificia Universidad Católica del Perú. [Consult. 01 set. 2017]; Disponível em: http://themis.pe;

- MARCÍlIO, Lucas.Estatuto da Pessoa com Deficiência e Reflexos na Incapacidade Civil: avanços e retrocessos. [Em linha]. ETIC, v. 13, n. 13. [Consult. 01 set. 2017]; Disponível em: www.intertemas.toledoprudente.edu.br/revista/índex;

- MARTINS, Ana Camilo. Cidadanias Esquecidas: o caso de pessoas com deficiência. [Em linha]. Universidade da Beira Interior: Covilhã. [Consult. 01 set. 2017]; Disponível em: https://ubibliorum.ubi.pt/handle/10400.6/2431;

- MENDES, Mariane Porto e SILVEIRA, Ingrid. Estupro de Vulnerável Consentido: diversas visões acerca da absolvição embasada no consentimento da vítima. "Revista da Jornada da Pós-Graduação e Pesquisa". Universidade da Região da Campanha;

- MONTEIRO, António Pinto.Das incapacidades ao Maior Acompanhado - Breve Apresentação da Lei 49/2018. Lisboa: CEJ, 2019, pp. 23-48;

- NASPOLINI, Ludmila. A Proteção aos Direitos da Pessoa com Deficiência. "Revista do CEJUR/TJSC". Rio Grande do Sul. v. V, n. 1, pp. 229-251;

- NEVES, Alexandra.O Estatuto dos "Cidadãos Invisíveis": o longo caminho para a plena cidadania das pessoas com deficiência. [Em linha]. Lisboa: Universidade Autónoma de Lisboa. [Consult. 01 jul. 2017]; Disponível em: http://repositorio.ual.pt; 
- PAZ, Margarida. O Ministério Público e o Novo Regime do Maior Acompanhado. Lisboa, CEJ, 2019, pp. 111-128;

- PIMENTEL, Susana e PIMENTEL, Mariana.Acessibilidades para a Inclusão da Pessoa com Deficiência: sobre o que estamos falando. "Revista FAEEBA". Salvador, v. 26, n. 50, pp. 91103;- RIBEIRO, Simone - Lei 13.146/2015 -Estatuto da Pessoa com Deficiência e suas Consequências: da incapacidade civil e interdição. [Em linha]. Porto Alegre: Universidade Federal do Rio Grande do Sul. [Consult. 01 set. 2017]; Disponível em: www.lume.ufrgs.br;

- PINHEIRO, Jorge Duarte.As Pessoas com Deficiência como Sujeitos de Direitos e Deveres: incapacidades e suprimentos - a visão do Jurista. [Em linha]. Lisboa. [Consult. 01 set. 2017]; Disponível em: https://www.icjp.pt/sites/default/files/media/600-886.pdf:

- SAMPAIO, Maria Carvalho.Regime Jurídico das Incapacidades: novo instituto para a protecção dos idosos. [Em linha]. Revista Julgar. [Consult. 01 set. 2017]; Disponível em: http://julgar.pt/wp-content/uploads/2016/12/20161209-ARTIGO-JULGAR-Regime-

Jur\%C3\%ADdico-das-Incapacidades-Novo-Regime-para-a-Prote\%C3\%A7\%C3\%A3o-dosIdosos-Concei\%C3\%A7\%C3\%A3o-Sampaio.pdf;

- SHIGEMATSU, Letícia.A Nova Perspectiva do Estatuto da Pessoa com Deficiência e seus Reflexos no Sistema de Incapacidades do Código Civil. [Em linha]. São Paulo: Centro Universitário António Eufrásio de Toledo. [Consult. 01 set. 2017]; Disponível em: http://intertemas.unitoledo.br;

- SILVA, Aurya. Novo Estatuto da Pessoa com Deficiência, e Suas Implicações a Curatela. [Em linha]. CARUARU: Centro Universitário Tabosa de Almeida. [Consult. 01 set. 2017]; Disponível em: http://repositorio.asces.edu.br/handle/123456789/832;

- SIMÕES, Cristina.O Direito à Autodeterminação das Pessoas com Deficiência. Porto: APPC-FDUP, 2016.

- SOUSA, António Pais.Da Incapacidade Jurídica dos Menores, Interditos e Inabilitados no Âmbito do Código Civil. Coimbra: Livraria Almedina, 1971;

- SOUSA, Miguel Teixeira de. O Regime de Acompanhamento de Maiores: alguns aspetos processuais. Lisboa: CEJ, 2019, pp: 39-60;

- STEFFEN, Luciana - Direitos Sexuais e Direitos Reprodutivos das Mulheres com Deficiência e o Blog "Sobre Rodas". "Anais do Congresso Latino-Americano de Gênero e Religião". São Leopoldo. V.5, pp. 401-407;

- SOALHEIRO, Luiza e CANÇADO, Paula - A Garota Dinamarquesa: reflexão sobre o direito fundamental à sexualidade. "Revista de Género, Sexualidade e Direito". Brasília, v. 3, n.1, pp. 116 ;

- TRABUCO, Cláudia - O Regime das Incapacidades e Respectivo Suprimento: perspectivas de reforma. [Em linha]. Lisboa: FDUNL. [Consult. 01 set. 2017]; Disponível em: www.fd.unl.pt/docentes_docs/ma/ct_MA_5013.doc; 